(Final version)

\title{
INNOVATION AND EXPORT PERFORMANCE: EVIDENCE FROM UK AND GERMAN MANUFACTURING PLANTS
}

\author{
Stephen Roper \\ School of Management and Economics and the \\ Northern Ireland Economic Research Centre \\ Queen's University Belfast, BT7 1NN, United Kingdom \\ e-mail: s.roper@qub.ac.uk \\ James H Love \\ Aston Business School, Aston University \\ Birmingham B4 7ET, United Kingdom \\ e-mail: j.h.love@aston.ac.uk
}

\begin{abstract}
Using comparable plant-level surveys we demonstrate significant differences between the determinants of export performance among UK and German manufacturing plants. Product innovation, however measured, has a strong effect on the probability and propensity to export in both countries. Being innovative is positively related to export probability in both countries. In the UK the scale of plants' innovation activity is also related positively to export propensity. In Germany, however, where levels of innovation intensity are higher but the proportion of sales attributable to new products is lower, there is some evidence of a negative relationship between the scale of innovation activity and export performance.
\end{abstract}

Significant differences are identified between innovative and non-innovative plants, especially in their absorption of spill-over effects. Innovative UK plants are more effective in their ability to exploit spill-overs from the innovation activities of companies in the same sector. In Germany, by contrast, non-innovators are more likely to absorb regional and supply-chain spill-over effects. Co-location to other innovative firms is generally found to discourage exporting.

Keywords: Innovation, Exports, Spill-over effects

\section{Acknowledgements}

We are grateful to three anonymous referees and to participants at the $28^{\text {th }}$ EARIE conference in Dublin for their constructive comments. Julie Anderson provided excellent research assistance. 


\section{Introduction}

The ability of a business or nation to generate export earnings is often seen as a key indicator of competitiveness and the ability to generate wealth. R\&D and innovation, involving the introduction of new products or the improvement of a firm's existing product range, play a key part in helping a firm to sustain or improve its market position. The relationship between innovation - usually interpreted as an indicator of the non-price competitiveness of a nation's products (e.g. Buxton et al., 1991) - and export success has therefore attracted attention as a potential explanation for nations' contrasting world trade performances. Thirwall (1986), for example, suggests that failure to keep pace with rising quality standards in international markets was a major factor in the UK's poor trade performance through to the 1980s. More recently attention has focussed on the comparative performance of the UK and German manufacturing sectors through direct plant-level comparisons of specific manufacturing activities (e.g. Mason and Wagner, 1994) and national or sectoral comparisons of trade performance (e.g. Wakelin, 1998; Anderton, 1999, 1999a). The results of the latter group of studies tend to reflect earlier work (e.g. Greenhalgh, 1990) suggesting that non-price qualities are a potentially important explanation of differences in trade performance. Anderton (1999), for example, finds that UK goods continue to be characterised by a higher degree of product substitutability than German goods. This, he suggests, may reflect the lower product quality of UK products relative to their German counterparts.

Although the sector in which a firm operates is an important element of the context within which decisions about the commitment of resources to R\&D and innovation is made, it is the firm which makes the investment decision and the firm which enjoys the rewards of innovation. The novel aspect of the present paper is the use of comparable plant-level data for the UK and Germany. This allows us to examine the impact of firms' actual innovation decisions on their export performance while taking into account the potential impact of sectoral influences and other aspects of firms' operating environment. Although strategic decisions on innovation and exporting are likely to be made at the firm level, they are implemented at the level of the individual plant, and will be based on the product market situation faced by those plants. The 
operating environment faced by plants within the same group may vary markedly, leading to different relationships between innovation and export performance, a subtlety that may be missed by firm-level analysis. For example, Dobkins (1996) highlights the potential for local agglomeration economies to impact on the innovation-export relationship, while the results of Wakelin (1998) suggest the importance of market sector. Other studies have suggested the importance of the quality of suppliers and the supply-chain in enabling both innovation and export growth (e.g. Crone and Roper, 2001; Görg and Ruane, 2000). The flexibility offered by plant-level data also enables us to assess the impact of different dimensions of innovation activity on export performance and to examine contrasts between innovative and non-innovative plants. Balancing these advantages is the lack of any comparable price data which limits our analysis to export propensity and restricts our range of explanatory factors to non-price influences. The analysis is restricted to the influence of product innovation on exports: the impact of process innovation is not considered.

The remainder of paper is organised as follows. Section 2 provides a brief overview of previous studies of the relationship between innovation and export behaviour at the sectoral and firm level. Section 3 specifies the conceptual framework adopted here and describes the main data sources. Section 4 describes the estimation results and section 5 concludes.

\section{Innovation and Trade}

Two main theoretical perspectives exist on the relationship between innovation and trade (Wakelin, 1998): 'neo-endowment' models in which specialisation is based on factor endowments of materials, labour capital and more recently human capital and knowledge; and, secondly technology based models such as the technology-gap theory of trade (Posner, 1961) and the life-cycle approach to trade (Vernon, 1966).

Several sectoral studies of trade flows adopt a technology-based perspective as their starting point suggesting that innovative industries will be net exporters rather than net importers, and that innovators will face lower price and higher income elasticities. 
Greenhalgh (1990), for example, in her examination of UK net exports for 31 sectors uses the SPRU database of significant innovations produced and used in each sector. She finds that in half the sectors considered, net exports gained from either intrasectoral or inter-sectoral innovation. In a subsequent extension of Greenhalgh's original analysis, Greenhalgh, Taylor and Wilson (1994) consider innovation effects on both net export volumes and export prices using both patents and the SPRU database of innovations as technology indicators ${ }^{1}$. In general terms these measures produce similar results to the earlier study, suggesting a consistent set of positive effects from the innovation measures on trade volumes and the balance of $\operatorname{trade}^{2}$.

Wakelin (1998) also adopts an approach from the technology gap tradition in her examination of sectoral trade flows for 22 industries and nine OECD countries. This study relates relative export flows to relative technology investments $(R \& D$, patents, and SPRU innovation rates in the UK). This study is notable, however, in that it allows for both intra-sectoral and inter-sectoral spill-overs from innovation activity on trade performance. Innovation in engineering sectors such as machinery, for example, may have a direct benefit for machinery exports but may also generate spill-over benefits for the export potential of other manufacturing sectors ${ }^{3}$. Wakelin's results also provide general support for a positive relationship between innovation and export flows, although this result proves sensitive to the use of different technology and innovation indicators.

Anderton (1999; 1999a) also considers the impact of R\&D and patenting activity on trade volumes and prices arguing that both technology indicators act as proxies for the quality and/or variety of goods being produced. Investments in technological development or innovation then allows countries to make technological improvements

\footnotetext{
${ }^{1}$ Greenhalgh Taylor and Wilson (1994) also consider the potential use of R\&D data as an innovation indicator but judged it to be 'an inferior variable to both of the available innovation output measures both statistically and conceptually [due to the] infrequency of measurement, long lags between R\&D inputs and the greater exogeneity in the timing and incidence of outputs' (p. 111).

${ }^{2}$ Greenhalgh et al. suggest that a stock measure of the innovation indicator proxying the stock of knowledge or past innovation would be a better indicator than flow measures such as R\&D investment or patents. In practice, however, because of the short length of their annual time series, they are forced to proxy true stock measures by three and five-year moving averages.

${ }^{3}$ See Dobkins (1996) for an analysis of similar inter-regional (or by analogy inter-sectoral) externalities in a spatial framework. Karunaratne (1997) adopts a related approach using telephone penetration per capita as a proxy for the effects of information technology innovations on Australian GDP growth.
} 
to their products, climbing a 'quality ladder' and shifting their export demand curve outwards and their import demand curve inwards. Anderton (1999) estimates import and export volume and import price equations for six broad industrial sectors in the UK. Both relative R\&D spending and relative patenting activity are found to have significant negative effects on import volumes but much weaker effects on export volumes and import prices. In a more specific exercise, Anderton (1999a) considers bilateral trade between the UK and Germany and focuses on import volumes and values using similarly defined technology variables. Again, the technology variables prove important in determining import volumes but unlike Wakelin (1998), Anderton (1999a) does find some evidence that relative $R \& D$ expenditure and patenting activity are more important in technology intensity industries (see also Ioannidis and Schreyer, 1997). Notably, however, Anderton (1999a) observes no difference between the importance of $\mathrm{R} \& \mathrm{D}$ and patenting activity between segmented and fragmented sectors, and no consistent differences between the effect of relative R\&D spending or patenting activity on import volumes in the UK and Germany.

Firm level studies of the trade-innovation relationship are typically more limited due to the lack of import volume and trade price data. Studies therefore focus on export volume or more specifically on export propensity i.e. the proportion of firms' sales which are exported. As with the sectoral studies considered earlier, however, alternative explanations of firms' export propensity are possible. First, firms' competitive advantage could be factor-based if the firm has either a natural monopoly of a particular factor or is, for example, located in a particular region where a factor is plentiful. If one extends the more traditional range of factors included in such models beyond labour and capital to include different dimensions of human and organisational resources, parallels between this type of explanation and resourcebased models of company competitiveness become obvious. The argument then becomes one of identifying the types of productive resources that determine firms' competitive advantage in export markets and their ability to export. Wakelin (1998a), for example, identifies positive links to average capital intensity while Sterlacchini (1999) identifies a positive relationship between the technological level of firms' capital stock and their export propensity. Another common finding is a positive but non-linear relationship between export propensity and plant size, a variable which 
may itself be acting as a proxy for the strength of firms' resource base ${ }^{4}$ (Kumar and Siddharthan, 1994; Wagner, 1995; Bernard and Wagner, 1997; Wakelin, 1998a; Bernard and Jensen, 1999; Sterlacchini, 1999).

A second, and non-exclusive explanation, is linked to firms' investments or achievements in implementing new technologies or the development of new products or processes. This itself is a socially-determined or evolutionary process shaped by the decision rules, learning capabilities and adaptive behaviour of firms (Metcalfe, 1997), social conventions (Morgan, 1997), and the intensity and extent of organisational and inter-personal interactions (Maillat, 1991; Grabher and Stark, 1997). The presence of an R\&D function within a firm, for example, may stimulate innovation through the type of technology-push process envisaged in linear models of innovation. R\&D staff may also, however, contribute to firms' creativity as part of multi-functional groups, or may allow firms to utilise extra-mural networks or information sources more effectively (Veugelers and Cassiman, 1999). Braunerhjelm (1996) provides evidence from Sweden that R\&D expenditures and investment in skilled labour both have a positive effect on firms' export intensity, while conventional cost factors have no effect. Braunerhjelm interprets these results as indicating that firm's international competitiveness depends on investment in firmspecific knowledge, not cost levels.

Other studies have stressed the potential importance of high-grade human resources for generating diversity and innovation. Commenting on their comparison of UK and German engineering and chemicals firms, Mason and Wagner (1994), for example, comment that " ... even those firms who have no aspirations to do more than adopt innovations developed elsewhere now increasingly require the services of highly qualified engineers and scientists in order to identify and make use of relevant information if they are to have any hope of staying in touch with more advanced

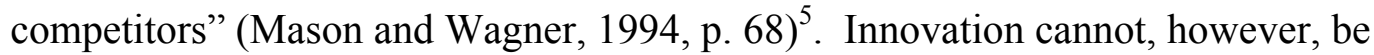

\footnotetext{
${ }^{4}$ The findings of Bernard and Wagner (1997) and Bernard and Jensen (1999) suggest that large and strong plants/firms tend to become exporters, rather than exporting enhancing performance.

${ }^{5}$ Relatively few empirical studies have until recently included variables explicitly reflecting the skill composition of firms' workforces as a determinant of innovation. See, for example, the material reviewed in Cohen (1995) and the papers included in Kleinknecht (1996). More recent studies based on firm or plant-level surveys have addressed the question, e. g. Shefer and Frenkel (1998), Love and Roper (2001).
} 
regarded purely as an internal matter; firms' external linkages or networks may also play a potentially important role (Oerlemans et al., 1998). Alongside their ability to release resource constraints, such external linkages may help by stimulating creativity, reducing risk, accelerating or upgrading the quality of the innovations made, signalling the quality of firms' innovation activities (Powell, 1998) and increasing firms' ability to appropriate the returns from innovation (Gemser and Wijnberg, 1995).

Firm-level studies relating innovation to export performance have the advantage of modelling firm-specific effects of innovation, but can be limited by the structure of their innovation data. Wakelin (1998a), for example, examines the impact of innovation on the export behaviour of UK manufacturing businesses using firm-level R\&D data and innovation data taken from the SPRU innovation study and company accounts. The longitudinal nature of the SPRU data allows Wakelin to consider the direct effect of being an innovative firm on export propensity, but provides little insight, for example, into the effect of the quality of innovations made on export propensity. Wakelin estimates probit models to identify exporters and related regression models for export propensity, and identifies significant differences in the determinants of export propensity for innovating and non-innovating firms. Estimated across all firms, however, Wakelin's results suggest that being an innovator significantly reduces both the probability of exporting and export propensity. Among innovative firms, however, the greater the number of innovations the more likely a firm is to be exporting. Spill-overs for both innovators and non-innovators are positive for the probability of innovating but negative for the extent of innovation. In contrast to the findings of Wakelin, however, Bernard and Jensen (1999) find that for a large sample of American plants, the introduction of new products significantly enhances the probability of exporting.

Wakelin (1998a) also finds significant differences between the effect on export propensity of different technology indicators (specifically R\&D spending and the SPRU innovation count data), a finding common to a number of other studies.

Lefebvre et al. (1998) for Canada and Bechetti and Rossi (1998) for Italian firms both find R\&D intensity has no impact on export propensity but that other innovation 
indicators have more positive effects ${ }^{6}$. This suggests that studies based solely on R\&D intensity may be misleading and that using a range of innovation indicators may be more appropriate (see also Brouwer and Kleinknecht, 1996). Kumar and Siddharthan (1994), for example, considered the role of $R \& D$ expenditure on the export propensity of 640 Indian firms from 1988 to 1990 and concluded that R\&D was a significant determinant of export propensity but only in low and medium technology industries. Similarly, Willmore (1992) relied on R\&D data as a technology indicator in his examination of the exports and imports of multi-nationals in Brazil. He identified no R\&D effect on exports but found that higher levels of domestic R\&D spending did reduce import propensity. Hirsch and Bijaoui (1985) also rely on R\&D spending in their examination of the export behaviour of Israeli firms, concluding that R\&D spend and lags are important in determining both the level and change in export propensity.

In a more recent study, Sterlacchini (1999) considers the role of innovation on the export performance of 143 small firms in non-R\&D intensive sectors in Northern and Central Italy. His approach is eclectic, considering both firms' product innovation activities as well as the technological and financial dimensions of firms' capital stock and organisational and market position. His results suggest that even in non-R\&D intensive industries innovation is an important determinant of small firms' export performance. Investment in innovative capital goods, and the importance of such goods in the firms' capital stock both matter as does size and the position of the firm in the value-chain (i.e. whether or not they are a subcontractor). "Thus, for small enterprises, reaching a minimum efficient size and attaining the status of 'independent firm' seem inescapable conditions for entering foreign markets. Thereafter, however, a firm's export performance depends significantly on its innovative efforts and the 'quality' of its capital stock.” (p. 830).

\footnotetext{
${ }^{6}$ Ito and Pucik (1993) in their analysis of Japanese manufacturing firms also found that R\&D intensity was insignificant in explaining export propensity when a size indicator is included in the equations.
} 


\section{Empirical Model and Data}

The social and evolutionary nature of the innovation process, and the evidence of previous empirical studies, suggests that any explanation of establishments' export propensity will need to take into account their own innovation activity and that of related or co-located companies. As previous studies in the neo-endowment tradition have also suggested that a range of enterprise characteristics may be important in determining export performance, our model will include a number of indicators of plants' operating and organisational characteristics. Further, as previous studies have shown that marked differences might be expected between different innovation indicators, particularly those representing inputs and outputs from the innovation process (e.g. Wakelin, 1998a), the nature of any innovation 'effect' on export propensity is also uncertain. On the one hand it may simply be an additive effect that can be adequately reflected by the inclusion of an innovation indicator in an export propensity equation. Alternatively, the interaction between innovation and export propensity may be more complex, with plants' innovation activity acting as an indicator of more fundamental differences between the organisation and structure of innovating and non-innovating plants. We test this proposition empirically, and where appropriate estimate separate export propensity equations for innovating and noninnovating establishments.

In addition to plant-specific factors we envisage three types of indirect innovation externality or spill-overs. First, it is possible that firms may derive some benefit from being located in a sector populated by innovative firms. For example, if firms in a particular industry are known to be producing innovative products this may act as a signal of product quality, boosting the exports of all firms in the industry whether or not they themselves are innovative. Alternatively, being located in an innovative industry may allow firms to improve the quality of the innovations they make, again boosting their export competitiveness. Secondly, inter-sectoral innovation spill-overs may be important with firms benefiting from innovations made in other sectors (Greenhalgh et al., 1994). Supply-chain spill-overs may be particularly important in this context as firms' innovation networks tend to be strongest with their customers and suppliers (e.g. Cooke et al., 1998; Roper, 2000). Thirdly, we might envisage 
locational economies or spill-overs linked to agglomeration or information flows of the type envisaged in Dobkins (1996) ${ }^{7}$.

The above discussion suggests a basic model of the form:

$$
\frac{X_{i t}}{S_{i t}}=\alpha+\beta_{0} R_{i t}+\beta_{1} I_{i t}+\beta_{2} L_{i t}+\beta_{3} S_{i t}+\beta_{4} Q_{i t}+\varepsilon_{i t}
$$

Where: $X_{i t} / S_{i t}$ is export propensity, i.e. the share of exports in total sales, $R_{i t}$ is a set of indicators of plants' resource endowments, $\mathrm{I}_{\mathrm{it}}$ is an indicator of product innovation, $\mathrm{L}_{\mathrm{it}}$ is an indicator of potential locational economies, $\mathrm{S}_{\mathrm{it}}$ sectoral economies and $\mathrm{Q}_{\mathrm{it}}$ supply-chain economies. In the estimated equations the significance of $\beta_{\mathrm{o}}$ will reflect the importance of plants' resource endowments to their export propensity, while $\beta_{1}$ will indicate any direct innovation effect. Parameters $\beta_{2}, \beta_{3}$, and $\beta_{4}$ will indicate the importance of any locational, sectoral and supply-chain externalities respectively.

The form of the dependent variable (i.e. export propensity) as a percentage of total sales means that OLS estimates would be biased and that the appropriate estimator is Tobit. As Cragg (1971) indicated, however, Tobit estimation imposes a sign restriction on the effect of each regressor on the probability of exporting and export propensity. The validity of this restriction can be tested against an alternative unrestricted form comprising separate probit and truncated regression models for the probability of exporting and export propensity respectively (Greene, 1993 p. 701-2). Wakelin (1998a) using UK data and Sterlacchini (1999) using Italian data both follow this procedure and reject the restriction implicit in the Tobit estimator. The same procedure is followed below with similar results. In addition to the overall estimation we consider whether the influence of plants' resource endowments and external environment on export propensity is the same for innovators and non-innovators. More specifically we consider whether $\beta_{0}, \beta_{2}, \beta_{3}$, and $\beta_{4}$ are the same for the two groups of plants.

\footnotetext{
${ }^{7}$ This type of agglomeration economies has been discussed extensively in the innovation literature. See Morgan (1997) and the other articles in the same special edition of Regional Studies for an overview.
} 
Data for the estimation are taken from the Product Development Survey (PDS), a postal survey which provides comparable information on the export and innovation activities of approximately 1700 UK manufacturing plants and 1300 German plants (see Roper et al., 1996; Love and Roper, 2001). This was equivalent to a response rate of 23.7 per cent in Germany and 20.6 per cent in the UK (Roper et al., 1996, Table A1.1). Plants responding to the PDS provided background information on the plant, details of the proportion of their total sales which were exported in 1991 and 1993, and information on their product innovation activities during the 1991-94 period. The sample was carefully selected to be representative of the industry, regional and sizeband distribution of manufacturing in each country (Roper et al, 1996, pp 61-66). Table 1 summarises the weighted responses for UK and German plants which provided information on their export activities. Although more German plants were engaged in exporting in 1991 and 1993, on average export markets accounted for a larger proportion of the sales of UK manufacturing plants.

(Table 1 here).

The first group of explanatory variables included in the export equations relates to the resource endowments and organisation of plants' production and other activities. These variables relate to whether the plant was part of a multi-plant group, the extent of skilled labour, the organisation of R\&D activity within the plant, and plant size.

The likely effect of being part of a multi-plant group on export propensity depends crucially on the position of the plant within the group's internal supply chain and on the group's marketing strategy. For example, if a plant is producing an intermediate product as part of a global supply chain, group membership may have a positive effect on export propensity by expanding intra-group trade. Alternatively, if a plant is producing a final good within a territorial marketing structure, group membership may effectively preclude any export activity. A priori it is difficult to say which effect is likely to be dominant, and so the coefficient sign is uncertain. Several pieces of empirical research indicate that the existence of skilled labour is likely to be positively linked to export performance, either through the effect of higher wages (Bernard and Jensen, 1999), or as an indicator of firm-specific knowledge or an enhanced resource base (Wakelin, 1998a; Wagner, 1995; Braunerhjelm, 1996). In the 
present study the proportion of graduates among plant employees is used to test for this skilled employment effect.

Another potentially important aspect of plants' resource base is whether the plant has an in-house $R \& D$ capability or formally organised $R \& D$ department. While this is clearly linked to the probability of innovating, R\&D capability may also act as more general indicator of the overall level of sophistication of the plant enabling it to absorb more readily external information (Veugelers and Cassiman, 1999), to manage and organise more effectively external or sub-contracted R\&D or innovation projects (Hertog and Thurik, 1993; Audretsch et al., 1996; Love and Roper, 2002), or act as a general indicator of investment in firm-specific knowledge (Braunerhjelm, 1996). We expect, therefore, that for any given set of plant characteristics and product innovation activity, the effect of R\&D on exporting is likely ceteris paribus to be positive. We test for this effect by the inclusion of two dummy variables. 'R\&D department' takes the value 1 where a plant has a formal unit devoted to conducting R\&D and zero otherwise; 'R\&D in plant' takes the value 1 where a plant conducts some $R \& D$ internally but on an ad hoc basis, and zero otherwise. Thus plants conducting no R\&D take the value zero for both dummies.

Plant size is generally expected to have a positive relationship to exports as larger plants have more resources with which to enter foreign markets. Wakelin (1998a) argues, for example, that this may be particularly important if there are fixed costs to exporting such as information gathering or economies of production and/or marketing which benefit larger firms. Scale may be important in overcoming such initial cost barriers but may then be less significant in determining the extent of firms' export activity. Support for this assertion comes from the non-linear relationship between plant-size and export propensity found by Kumar and Siddharthan (1994), Wagner (1995), Willmore (1992), Wakelin (1998a), Bernard and Jensen (1999) and Sterlacchini (1999), each of which identifies an inverted-U shape relationship. We therefore include both plant size and its square in the estimated models, and expect to find a quadratic relationship.

The second group of explanatory variables considered in the model are alternative indicators of innovation, reflecting different dimensions of plants' product innovation 
activities. We deal here exclusively with output indicators of innovation: as indicated above, $R \& D$ investment is regarded not as an indicator of innovation per se, but as an indicator of investment in the resource base of the plant. ${ }^{8}$ Table 1 gives the average value for each of these indicators for the UK and German samples and Table 2 reports the correlation coefficients between the innovation indicators and export propensity. The first innovation indicator is a simple binary indicator which takes value one if the plant introduced any new or improved products during the 1991 to 1994 period, and zero otherwise. This measure reflects a broad interpretation of the meaning of innovation, setting no formal technological criteria and interpreting innovation as a business rather than technological process (see Roper et al., 1996, p. 2). This view is supported by research from the US (Audretsch, 1995) which indicates that over 90 per cent of commercially significant product changes involve no technological advance. For our sample of plants, 57 per cent of UK plants and 56 per cent of German plants were classified as 'innovators' using this definition (Table 1). The remaining innovation indicators are more quantitative in nature and reflect differences in the extent or success of plants' innovation activity. The second innovation measure is innovation intensity, defined as the number of product changes made by the plant per employee. This variable, which tends to be lower in larger plants, was on average higher among German plants (0.41) than among their UK (0.31) counterparts. The third innovation indicator available from the PDS is innovation 'success', defined as the proportion of each plant's 1994 sales derived from products newly introduced over the 1991 to 1994 period. In the UK this averaged 25 per cent in 1994 compared to 23 per cent in Germany. ${ }^{9}$ In each case we expect a positive relationship between the innovation indicators and export propensity.

(Table 2 here)

The final group of explanatory variables included in the export equations relates to the possibility of sectoral, locational and supply-chain spill-overs. In each case the

\footnotetext{
${ }^{8}$ There is a considerable literature stressing the weakness of input measures such as $\mathrm{R} \& \mathrm{D}$ as indicators of innovation (e.g. Audretsch, 1995; Kleinknecht, 1996). Table 2 shows that the correlation between the measures of $R \& D$ and innovation indicators is modest, ranging from -0.180 to 0.314 .

${ }^{9}$ The correlations between the innovation indicators are positive but relatively weak, ranging from a minimum of 0.051 between the $0 / 1$ identifier for innovators and innovation success, and 0.289 between innovation success and innovation intensity (Table 2).
} 
variables are measured as the average level of innovation intensity in the sector and region in which the plant is operating, or the sectors supplying each plant ${ }^{10}$. As we expect high levels of sectoral, regional or supply-chain innovation intensity to have positive benefits for the competitiveness of each plant we expect positive coefficients on each of the spill-over variables. To test for the possibility of learning effects, we also allow for interactions between plant R\&D capability and the spill-over terms. ${ }^{11}$

\section{Estimation Results}

We first consider the importance of innovation for export performance among the whole sample of UK and German manufacturing plants. Significant differences emerge, however, between the determinants of export performance for innovators and non-innovators. These differences are discussed in Section 4.2.

\subsection{Whole Sample Results}

Table 3 reports equations for export performance estimated for each national sample, with observations being weighted to reflect the sampling structure. Part A of Table 3 reports in full equations including the qualitative innovation indicator, relating to whether each plant had introduced any new or improved products over the 1991-94 period. Part B of Table 3 reports the (marginal) coefficients on the two quantitative innovation indicators in identical equations. Each equation also included a series of

\footnotetext{
${ }^{10}$ The supply-chain spill-over variable was constructed to represent the innovativeness of the supply chain of each sector. The variable is constructed as a weighted average of innovation intensity in the domestic manufacturing sectors which supply each industry. Average innovation intensity in the supplying sectors is taken from the PDS survey. The weights are derived from the Leontief inverse of the UK input-output table for 1990. (Source: Input-Output Table for the UK, $10^{\text {th }}$ Edition, CSO 1995, Table 5). That is if $\mathrm{I}_{\mathrm{jt}}$ is the sectoral average of innovation intensity (i.e. innovations per employee) and $\mathrm{P}_{\mathrm{ijt}}$ is the level of purchases by plants in sector $\mathrm{i}$ from those in sector $\mathrm{j}$ the supply-chain spill-over variable $Q_{i t}$ is defined as:

$$
Q_{i t}=\sum_{j \neq i}^{9} I_{j t} \frac{P_{i j t}}{\sum_{j \neq i}^{9} P_{i j t}}
$$

Note, that the sectoral structure used is that in Roper et al. (1996) which identifies ten manufacturing sectors (see also footnote 12). Intra-sectoral purchases are excluded.

${ }^{11} \mathrm{We}$ are grateful to an anonymous referee for suggesting the extension to the analysis.
} 
industry dummy variables (not shown) intended to correct for industry specific factors ${ }^{12}$.

The first notable feature of the equations is that, like Wakelin (1998a) and Sterlacchini (1999), likelihood ratio (LR) tests reject the restriction implicit in Tobit estimation $^{13}$, indicating that there are significant differences in the impact of the independent variables on the probability of exporting and plants' export propensity (i.e. the proportion of their sales derived from exports). This applies to both the UK and Germany and to the equations including each of the three innovation indicators (Table 3). Instead of a single Tobit model we therefore report separate models of the probability of exporting covering all plants and export propensity covering exporting plants only. One attractive feature of the unrestricted form of the model is that it allows us to identify separately the effect of innovation on the probability of exporting and plants' export propensity. This may be important as Sterlacchini (1999) finds, for example, that the extent of firms' innovative activity plays relatively little part in explaining the probability of exporting but is important in explaining the extent of firms' export activities.

(Table 3 here)

The second notable feature of the UK and German export probability and export propensity equations is the strong positive coefficient on the qualitative innovation indicator. For both the UK and Germany, undertaking product innovation has a positive effect on the probability of exporting, but has no statistically significant effect on export propensity (Table 3, part A). This suggests that in both economies the product quality advantages derived from innovation allow plants to enter export markets more readily but not to expand the scale of their export sales. The results of Wakelin (1998a), however, suggest the need for caution in the interpretation of this

\footnotetext{
${ }^{12}$ Seven industry dummies were included for: textiles and clothing (Nace 17,18, 19), paper and printing (Nace 21,22), chemicals (Nace 24), metals and fabrication (Nace 27,28), mechanical engineering (Nace 29), electrical and optical engineering (Nace 30,31,32 and 33), transport equipment (Nace 34, 35). Dummies omitted to avoid collinearity were: food, drink and tobacco (Nace 15,16), wood and wood products (Nace 20), and other manufacturing sector (Nace 25, 26, 36, 37). Complete versions of the reported equations are available from the authors on request.

${ }^{13}$ These are LR tests 1-3 in Table 3.
} 
result based as it is on a single qualitative indicator of innovation activity. In particular, her results suggest the need to examine the sensitivity of the innovationexport behaviour relationship to using alternative indicators of innovation activity. Part B of Table 3 therefore reports comparable coefficients for the other quantitative innovation indicators (i.e. innovation intensity and innovation success) derived from similar equations to those given in Part A. Innovation intensity, a measure of the volume of plants' innovation outputs, has no significant effect on export probability or propensity. Innovation success, a measure of the commercial success of innovation, has a positive and significant effects on UK export propensity, but a slightly negative effect on German export probability.

Taken together the estimated coefficients on the three innovation indicators emphasise the importance of the innovation-export relationship. Slight differences emerge, however, between UK and German plants in the nature of this relationship. In the UK, both being a product innovator and the success of plants' innovation activities are positively related to the probability and propensity to export respectively. In Germany, although being a product innovator has an important positive impact on plants' export probability, the scale of plants' innovation activities has a negative effect on export probability.

These results may reflect the relative positioning of UK and German enterprises in terms of the international competitiveness of their product offerings, and the average levels of R\&D investment in the two national economies. For those UK plants starting with relatively low average levels of R\&D investment, the returns to innovation in terms of their increased ability to enter export markets and increase export sales is clear. Innovation, and the success of product innovation, both have positive export effects. For German plants competing in a less price sensitive home market where quality criteria are more rigorous (Anderton, 1999) innovation is still beneficial in entering export markets. However, as plants are already having to invest heavily in $R \& D$ to compete in their home market, further increases in the scale of innovation activity produce less clear returns in terms of exporting than in the UK. One interpretation is that this is simply a product life-cycle issue ${ }^{14}$; initially German firms

\footnotetext{
${ }^{14} \mathrm{We}$ are grateful to an anonymous referee for suggesting this interpretation.
} 
obtain the greatest marginal return from sales in their sophisticated home market, with a lag before technology stabilises and export markets become profitable.

Alternatively, however, our results may suggest that for German plants a strategic trade-off exists between increasing innovation activity and export market development. This is perhaps easiest to see in managerial terms with German firms facing a choice as to whether to focus on product development specifically for the home market or to allocate fewer resources to innovation and more to developing new export markets.

Other plant-level factors, reflecting the strength of plants' resource-base, also proved important in shaping export behaviour. Being part of a multi-plant group, for example, with its potential for intra-company financial and technology transfers, has a positive effect on export propensity in both the UK and Germany. This suggests that the globalisation or internationalisation of production or marketing by multi-plant groups dominates any strategic moves to segment international markets along national boundaries and so limit the export activities of group members. Skilled labour has the expected positive effect on export probability and propensity in the UK, but has a significantly negative effect on German export probability. This may reflect the very different involvement of skill groups in the innovation activities of UK and German plants. In particular, UK plants more commonly involve scientific, technological, design and marketing staff in their innovation activities than German plants where innovation is more strongly dominated by engineering staff, possibly with intermediate rather than graduate-level qualifications (Roper et al., 1996, pp. 28-33).

The presence of an R\&D capability in a plant is measured by two dummy variables, distinguishing between the effect of a simple ad hoc presence of R\&D, and the additional effect attributable to the existence of a formal R\&D department at plant level. Some differences exist between theses effects for the two countries, with both R\&D measures having a positive effect on UK plants' export propensity, while in Germany the positive effects are exclusively on the probability of exporting. Plant size, potentially reflecting economies of scale and the overall strength of plants' resource base, is also positively related to both export probability and propensity, although the size coefficients in the export propensity equations are insignificantly different from zero. As expected from previous studies discussed earlier, the plant 
size-exporting relationship is non-linear, having an inverted U-shape relationship, suggesting that the probability of exporting increases less than proportionately with plant size. For both the UK and German samples, however, the estimated coefficients are such that the vast majority of plants are on the upward sloping part of the curve, i.e. on the region of the curve where increases in plant size are associated with increased export probability ${ }^{15}$. The implication is that the more extensive resource base of larger companies does facilitate them in entering export markets, but that this effect is more significant for smaller firms. Large size appears to confer no beneficial effect on export propensity.

The final group of variables included in the export behaviour equations are intended to reflect the benefits to plants' export activity of innovation undertaken elsewhere, i.e. to reflect spill-overs from other plants' innovation activity. Sectoral spill-overs, are found to have a positive effect on UK plants' export probability and propensity, but no effect in Germany (Table 3, Part A). This is consistent with the idea that UK plants operating in an innovative domestic sector may benefit from the innovative 'image' or signal associated with their sector when entering export markets. To test for the possibility that these are actual technological spill-overs an interaction term is included between the existence of a formal R\&D department and the sectoral effect. A positive effect on such an interaction would indicate that the existence of formal R\&D helps plants to absorb technological spill-overs from other plants: no such effect is detected, suggesting that the positive sectoral effect in the UK derives from signalling benefits. The lack of such a signalling effect among German plants suggests that their export performance depends more directly on their own resourcebase and innovation activity.

Regional or locational effects have received considerable recent attention in both the innovation (Shefer and Frenkel, 1998) and trade (Dobkins, 1996) literatures. Dobkins (1996), for example, suggests that local agglomeration economies related to innovation might contribute to improved export performance by co-located firms. In fact, however, our results suggest the opposite with plants in regions characterised by high levels of innovative activity having lower export probability (Germany) and

\footnotetext{
${ }^{15}$ The turning points for the equations in Table 3 are: UK export probability, 7650 employees; German
} 
propensity (UK). Two possible explanations might be envisaged. One is that the regional spill-overs variable is actually reflecting a demand-side effect rather than the type of supply-side agglomeration effects envisaged by Dobkins (1996). In particular, high levels of innovative activity tend to be associated with higher regional incomes, and greater local demand in these areas may be reducing the need for local firms to export. This explanation can be discounted, however, because of the consistently positive effect of regional GDP on export probability and propensity. A second possibility is that, ceteris paribus, firms with strong export orientation tend to locate in more peripheral regions of a country to take advantage of lower factor prices and it is these regions which also tend to have lower innovation intensity. The current dataset can shed no light on this possibility.

The final type of spill-over effect envisaged is that from plants' domestic supply chain, where it is anticipated that plants supplied by more innovative sectors are likely to have greater export potential. In Germany this type of positive spill-over is observed, with export probability (but not export propensity) positively related to the extent of innovation in the plants' supply-chain. In the UK, by contrast, having more innovative suppliers is linked to a small reduction in export probability, but to an increase in export propensity. However, the negative effect on UK plant's export probability is more than offset by a positive interaction between supply-chain innovation and formal plant-level R\&D, suggesting that there may be some form of learning spill-over between R\&D-intensive plants and their innovative suppliers.

\subsection{Export Performance of Innovators and Non-Innovators}

The importance of the innovation indicators in the export performance equations of Table 3, and the findings of Wakelin (1998a), suggest that the determinants of export performance may be different for innovators and non-innovators. Geroski et al. (1993), for example, suggest that innovators and non-innovators may behave differently reflecting either the accumulated benefits of past innovation or some generic difference such as better management. To test this assertion we split the variables in the equations into those observations relating to innovators and those

export probability, 2830 employees. 
relating to non-innovators and, estimating probit and truncated regression models for innovators and non-innovators together, use a Wald test to test the restriction that the coefficients in the two parameter vectors are the same. For both the UK and Germany the restriction that the whole group of plant-specific, size and spill-over coefficients is the same for innovators and non-innovators is rejected in the probit models, but not in the truncated regression models ${ }^{16}$. In other words, for plants in both countries innovators and non-innovators differ in the factors which make them exporters, but once the exporting decision is made, innovators and non-innovators do not differ in the determinants of export propensity

Reflecting the different explanations of export behaviour suggested by the Wald tests, Table 4 reports separate export probability models for innovators and non-innovators. In each group of equations the first model relates solely to non-innovators, with the other models including the two quantitative indicators of innovation activity in turn. The key finding from Table 4 is that, for both countries, innovators and noninnovators show relatively little difference in the plant-specific determinants of export probability, but marked differences in the way in which spill-overs affect their export likelihood. For example, the effect of plant size and graduate employment varies little between innovators and non-innovators, although in Germany the positive effects of group membership and in-house $R \& D$ are restricted to the innovating group. And in both countries, the positive effect of regional GDP per capita on export probability is restricted to the innovating sub-sample.

(Table 4 here)

Much more marked is the differential way in which innovators and non-innovators are affected by spill-over effects. In the UK, the positive sectoral effect noted in Table 3 is found in Table 4 to be restricted almost entirely to innovators; the same is true of the negative effect on export probability of the regional and supply chain spill-over effects. As with the overall results of Table 3, the negative supply-chain spill-over

\footnotetext{
${ }^{16}$ The null hypothesis of the Wald test is that the equality restriction on the coefficients relating to innovators and non-innovators is valid. The test statistics were as follows: UK probability of exporting $\chi^{2}(9)=33.47, \rho=0.0001$; UK export propensity $\chi^{2}(10)=9.11, \rho=0.521$; German probability of exporting $\chi^{2}(10)=23.81, \rho=0.008$; German export propensity $\chi^{2}(10)=11.43, \rho=0.325$. The tests imply rejection of the restriction for the probability of exporting, but not for export propensity.
} 
effect is partly offset among innovators by a positive interaction term with the presence of a formal R\&D department, again implying learning spill-overs between R\&D-intensive plants and their innovative suppliers. In Germany, the results for the entire sample (Table 3) detected no sectoral spill-over effect, but strongly negative regional and strongly positive supply-chain spill-over effects on export probability. The results of Table 4 show that these effects are entirely restricted to the noninnovating plants in the sample. Thus for both countries the spill-over effects are restricted to one group of plants: but while the spill-over effects identified for the UK sample as a whole occur entirely as a result of their influence on the innovative plants in the sample, for the German plants the effect is entirely on non-innovators.

Overall, the results suggest that the resource endowments and internal capabilities of manufacturing plants have, with few exceptions, similar effects on the export performance of innovators and non-innovators. More interesting, however, are the differences between innovating and non-innovating plants in terms of the effects of the locational and sectoral operating environment, where there is evidence that spillover effects vary markedly between innovators and non-innovators. However, these variations are not consistent between the two countries.

\section{Conclusions}

The research reported here has used plant-level data to perform a comparative analysis of the link between product innovation and export performance of UK and German manufacturing plants. The results suggest that the link identified in previous research between innovation and export performance at the firm level is also evident at the level of the individual manufacturing plant. There is evidence that product innovation, however measured, has an effect on both the probability and propensity to export of plants in both countries. There is, in addition, evidence that the nature of this effect varies between the countries. In the UK, being a product innovator and the success of plants' innovation activities are positively related to the probability and propensity to export respectively. In Germany, although being a product innovator has an important positive impact on plants' export probability, the scale of plants' innovation activities has a slight negative effect on export probability. We interpret 
these results as reflecting the relative positioning of UK and German manufacturing plants in terms of the international competitiveness of the product offerings. The findings may simply be a result of differential product life-cycle effects, but could indicate that for German plants a strategic trade-off exists between increased innovation activity and the developments of export markets, while no such trade-off exists for UK plants

The econometric results also suggest that the determinants of export probability (but not the extent of exporting) differ between innovators and non-innovators. In the UK, spill-overs affect mainly innovating plants. Clearly it pays to innovate, and innovators benefit from being in an innovative sector; but there is little evidence that non-innovators can benefit from the 'halo effect' of being in a highly innovative sector. By contrast, location in a highly innovative geographical region is likely to be detrimental to the export probability of UK manufacturing plants, but only if they innovate. In Germany, however, spill-overs affect non-innovating plants' export probability, but have (virtually) no effect on the exporting behaviour of innovators.

These results have implications for two areas of public policy interest. The first relates to the nature of the differences between innovators and non-innovators. Geroski et al. (1993) point out that the positive correlation between innovation and firm performance that they find may either be because firms derive some transitory benefit from the introduction of a new product, or because the process of innovation positively transforms the innovating firms' internal capabilities, indicating permanent differences in the internal capabilities of innovating firms. By analysing a large sample of UK firms, Geroski et al. conclude that it is the latter effect which predominates, and that it is process of innovating that gives rise to the improved internal capabilities of innovating firms which distinguishes them from noninnovators. In particular, they conclude that innovators are better able to realize the benefits of spill-overs than non-innovators, which helps improve their relative performance $^{17}$. Our results suggest two points which complement this research. First, we too find differences in the abilities of innovators and non-innovators to benefit

\footnotetext{
${ }^{17}$ Note, however, the subsequent findings of Geroski et al. (1997) which suggest that relatively few firms innovate persistently, suggesting that fundamental differences between innovators and non-
} 
from spill-over effects, but find that this difference extends to regional and supplychain spill-over effects as well as the sectoral spill-overs considered by Geroski et al. Secondly, differences in the abilities of innovators and non-innovators to absorb the effects of spill-overs are not consistent across countries, and may be a function of the international competitive position of the country concerned. Unlike UK plants, the exporting behaviour of German manufacturing plants becomes less affected by spillover effects when they innovate. Thus in Germany, the act of innovating seems to make the resource endowments, internal capabilities and internal organisation of the individual plant more important in the decision to export, while these factors become relatively less important for UK plants' exporting decisions after innovation occurs.

The second area of policy concern relates to research indicating that geographical clusters are beneficial for the innovative performance of business enterprises (Baptista and Swann, 1998). Although clusters may be good for innovation, and although innovating may be good for export performance at the level of the individual plant, our results suggest caution in concluding that geographical clusters are beneficial for the performance of firms located in such clusters. This is because being located in a highly innovative region reduces export performance, although in different ways in the two countries. As indicated earlier, this is unlikely to reflect the demand-side effects of being located in high-innovation, high-income regions, and implies a negative supply-side agglomeration effect. The strength and consistency of this effect suggests that calls for public spending to encourage the development of innovative clusters might usefully consider not merely the possible innovation-inducing effect of such clustering, but the impact on export performance which may result from such activity. 
Table 1: Export Performance and Innovation Measures: Descriptive Statistics for UK and German Manufacturing Plants

\begin{tabular}{lccc}
\hline & UK & Germany & Total \\
Number of Plants & 1087 & 1190 & 2277 \\
\hline & & & \\
A. Exporting Plants (\% plants) & 39.1 & 48.3 & 45.0 \\
Exporting Plants 1991 & 44.3 & 56.0 & 51.8 \\
Exporting Plants 1993 & & & \\
& & & \\
B. Export Propensity (\% sales) & 18.4 & 16.0 & 16.6 \\
Percentage Exports 1991 & 20.8 & 17.3 & 18.3 \\
Percentage Exports 1993 & & & \\
& 57.4 & 56.0 & 56.5 \\
C. Innovation Measures & 0.31 & 0.41 & 0.37 \\
Product innovator (\% plants) & 24.7 & 22.9 & 23.5 \\
Innovation intensity (innovations per emp) & & & \\
New products (\% sales) & & & \\
& & & \\
\hline
\end{tabular}

Note: Observations are weighted to give representative results (see Roper et al., 1996, Appendix 1). 
Table 2: Correlations Between R\&D, Innovation and Export Propensity Measures for UK and German Plants

\begin{tabular}{|c|c|c|c|c|c|c|c|}
\hline & $\begin{array}{c}\text { Export } \\
\text { Propensity } \\
1993 \\
\end{array}$ & $\begin{array}{c}\text { Export } \\
\text { Propensity } \\
1991 \\
\end{array}$ & $\begin{array}{l}\text { Product } \\
\text { Innov }\end{array}$ & $\begin{array}{c}\text { Innov } \\
\text { intensity }\end{array}$ & $\begin{array}{c}\text { New } \\
\text { Products } \\
\% \text { of sales } \\
\end{array}$ & $\begin{array}{l}\text { R\&D } \\
\text { Dept. }\end{array}$ & $\begin{array}{l}\text { R\&D } \\
\text { in-plant }\end{array}$ \\
\hline Export Propensity 1993 & 1.000 & & & & & & \\
\hline Export Propensity 1991 & 0.937 & 1.000 & & & & & \\
\hline Product Innovation & 0.207 & 0.250 & 1.000 & & & & \\
\hline Innovation intensity & -0.084 & -0.074 & 0.183 & 1.000 & & & \\
\hline $\begin{array}{l}\text { New Products as \% of } \\
\text { sales }\end{array}$ & -0.086 & 0.125 & 0.051 & 0.289 & 1.000 & & \\
\hline R\&D Department & 0.159 & 0.166 & 0.314 & 0.110 & 0.146 & 1.000 & \\
\hline $\mathrm{R} \& \mathrm{D}$ in-plant & -0.066 & -0.057 & -0.180 & -0.102 & -0.156 & -1.000 & 1.000 \\
\hline
\end{tabular}

Note: Observations are weighted to give representative results (see Roper et al., 1996, Appendix 1). 
Table 3: Probit and Truncated Regression Models of Innovation and Export Propensity in UK and German Manufacturing Firms

\begin{tabular}{|c|c|c|c|c|}
\hline \multirow[b]{2}{*}{ Dependent Variable } & \multicolumn{2}{|c|}{ UK } & \multicolumn{2}{|c|}{ Germany } \\
\hline & $\begin{array}{c}\text { Export } \\
\text { Indicator } \\
0 / 1 \\
\end{array}$ & $\begin{array}{c}\text { Export } \\
\text { Propensity } \\
\%\end{array}$ & $\begin{array}{c}\text { Export } \\
\text { Indicator } \\
0 / 1 \\
\end{array}$ & $\begin{array}{c}\text { Export } \\
\text { Propensity } \\
\%\end{array}$ \\
\hline \multicolumn{5}{|l|}{ Part A } \\
\hline Constant & $\begin{array}{c}-0.452 \\
(-0.253)\end{array}$ & $\begin{array}{c}-49.316^{* *} \\
(-3.182)\end{array}$ & $\begin{array}{c}-0.511 * * \\
(-3.809)\end{array}$ & $\begin{array}{c}-44.199 * * \\
(-3.332)\end{array}$ \\
\hline Part of Multi-plant Group & $\begin{array}{c}0.030 \\
(1.140)\end{array}$ & $\begin{array}{c}5.236^{* *} \\
(2.962)\end{array}$ & $\begin{array}{c}0.066 \\
(1.088)\end{array}$ & $\begin{array}{l}3.566^{*} \\
(1.641)\end{array}$ \\
\hline Graduate Employees & $\begin{array}{c}0.007 * * \\
(3.557)\end{array}$ & $\begin{array}{c}0.174 * * \\
(2.943)\end{array}$ & $\begin{array}{c}-0.003 * * \\
(-2.922)\end{array}$ & $\begin{array}{c}-0.051 \\
(-0.720)\end{array}$ \\
\hline R\&D Department in Plant & $\begin{array}{c}-0.793 * * \\
(-2.002)\end{array}$ & $\begin{array}{c}36.222^{*} \\
(1.753)\end{array}$ & $\begin{array}{c}0.893^{* *} \\
(2.428)\end{array}$ & $\begin{array}{l}-11.012 \\
(-1.087)\end{array}$ \\
\hline R\&D in Plant & $\begin{array}{c}0.157 \\
(0.527)\end{array}$ & $\begin{array}{c}9.317 * * \\
(3.736)\end{array}$ & $\begin{array}{l}0.136^{* *} \\
(3.264)\end{array}$ & $\begin{array}{c}0.691 \\
(0.387)\end{array}$ \\
\hline Plant Employment $\left(\mathrm{x} 10^{3}\right)$ & $\begin{array}{c}0.297 * * \\
(2.381)\end{array}$ & $\begin{array}{c}1.182 \\
(0.393)\end{array}$ & $\begin{array}{c}0.921^{* *} \\
(3.813)\end{array}$ & $\begin{array}{c}1.813 \\
(0.471)\end{array}$ \\
\hline Plant Employment (Squared) & $\begin{array}{r}-0.019 * * \\
(-2.062)\end{array}$ & $\begin{array}{c}-0.067 \\
(-0.266)\end{array}$ & $\begin{array}{c}-0.162 * * \\
(-3.616)\end{array}$ & $\begin{array}{c}-0.211 \\
(-0.263)\end{array}$ \\
\hline Product Innovation & $\begin{array}{c}0.134 * * \\
(4.394)\end{array}$ & $\begin{array}{c}0.307 \\
(0.144)\end{array}$ & $\begin{array}{c}0.146^{* *} \\
(4.658)\end{array}$ & $\begin{array}{c}2.119 \\
(1.235)\end{array}$ \\
\hline Regional GDP per Capita & $\begin{array}{c}0.003 * * \\
(2.593)\end{array}$ & $\begin{array}{c}0.016 \\
(0.268)\end{array}$ & $\begin{array}{l}0.002 * * \\
(2.993)\end{array}$ & $\begin{array}{l}0.080^{*} \\
(1.928)\end{array}$ \\
\hline Sector & $\begin{array}{c}0.068^{* *} \\
(2.836)\end{array}$ & $\begin{array}{l}2.403^{*} \\
(1.698)\end{array}$ & $\begin{array}{c}-0.009 \\
(-0.307)\end{array}$ & $\begin{array}{c}-0.208 \\
(-0.065)\end{array}$ \\
\hline Region & $\begin{array}{c}-0.041 \\
(-0.926)\end{array}$ & $\begin{array}{c}-12.935^{* *} \\
(-3.148)\end{array}$ & $\begin{array}{c}-0.353 * * \\
(-3.238)\end{array}$ & $\begin{array}{c}0.672 \\
(0.087)\end{array}$ \\
\hline Supply Chain & $\begin{array}{l}-0.703^{*} \\
(-1.890)\end{array}$ & $\begin{array}{c}74.957 * * \\
(2.296)\end{array}$ & $\begin{array}{l}1.022^{* *} \\
(4.329)\end{array}$ & $\begin{array}{l}30.118 \\
(1.095)\end{array}$ \\
\hline Sector x R\&D Department & $\begin{array}{c}0.224 \\
(0.857)\end{array}$ & $\begin{array}{c}-4.935 \\
(-1.433)\end{array}$ & $\begin{array}{c}0.041 \\
(0.235)\end{array}$ & $\begin{array}{c}0.975 \\
(0.244)\end{array}$ \\
\hline Region x R\&D Department & $\begin{array}{c}0.261 \\
(1.404)\end{array}$ & $\begin{array}{c}4.244 \\
(0.735)\end{array}$ & $\begin{array}{c}-0.857 * * \\
(-3.305)\end{array}$ & $\begin{array}{c}-1.395 \\
(-0.111)\end{array}$ \\
\hline Supply Chain x R\&D Dept. & $\begin{array}{c}2.014^{* *} \\
(2.103)\end{array}$ & $\begin{array}{l}-70.670 \\
(-1.394)\end{array}$ & $\begin{array}{c}-1.131 \\
(-1.239)\end{array}$ & $\begin{array}{l}30.118 \\
(1.095)\end{array}$ \\
\hline $\begin{array}{l}\mathrm{N} \\
\text { Log Likelihood } \\
\mathrm{LR}_{1} \chi^{2}(22)\end{array}$ & $\begin{array}{c}861 \\
-342.75 \\
18\end{array}$ & $\begin{array}{c}695 \\
-2935.6 \\
.07\end{array}$ & $\begin{array}{r}1118 \\
-473.93 \\
25\end{array}$ & $\begin{array}{c}842 \\
-3496.7 \\
.36\end{array}$ \\
\hline \multicolumn{5}{|l|}{ Part B } \\
\hline Innovation Intensity & $\begin{array}{c}-0.000 \\
(-0.002)\end{array}$ & $\begin{array}{c}-0.551 \\
(-0.695)\end{array}$ & $\begin{array}{c}0.019 \\
(0.942)\end{array}$ & $\begin{array}{c}-1.675 \\
(-1.112)\end{array}$ \\
\hline $\mathrm{LR}_{2} \chi^{2}(22)$ & \multicolumn{2}{|c|}{141.74} & \multicolumn{2}{|c|}{226.56} \\
\hline Innovation Success $\left(\mathrm{x} 10^{2}\right)$ & $\begin{array}{c}-0.044 \\
(-1.098)\end{array}$ & $\begin{array}{c}11.335^{* *} \\
(2.728)\end{array}$ & $\begin{array}{l}-0.103 * \\
(-1.862)\end{array}$ & $\begin{array}{c}-6.515 \\
(-1.271)\end{array}$ \\
\hline $\mathrm{LR}_{3} \chi^{2}(22)$ & \multicolumn{2}{|c|}{142.54} & \multicolumn{2}{|c|}{182.84} \\
\hline
\end{tabular}




\section{Notes}

1. Reported coefficients are marginal values calculated at variable means.

Observations were weighted to take account of sample structure and all equations included industry dummies that are not reported. Truncated regression models are estimated for exporting firms only.

2. t-statistics in parentheses. Significant at $* * 5 \%, * 10 \%$ on a two-tailed test.

3. The $\chi^{2}$ tests reported test the restriction implicit in using a single Tobit model rather than separate probit and truncated regression models (Greene, 1993, pp. 701-702). Test $L_{1}$ relates to the models presented in Part $A . L_{2}$ and $L R_{3}$ relate to identical models including the alternative innovation indicators, i.e. innovation intensity and innovation success.

4. For the UK probit model the equation $\chi^{2}=158.72$ and the overall percentage of correct predictions was 79.5 per cent $(23.5 \%$ for non-exporters and $92.9 \%$ for exporters). For the German probit model the equation $\chi^{2}=301.76$, and the overall percentage of correct predictions was 78.8 per cent (40.9\% for non-exporters and $91.2 \%$ for exporters). 
Table 4: Probit Models of Export Probability for UK and German Innovators and Non-Innovators

\begin{tabular}{|c|c|c|c|c|c|c|}
\hline \multirow[t]{2}{*}{ Dependent Variable } & \multicolumn{3}{|c|}{ UK Plants } & \multicolumn{3}{|c|}{ German Plants } \\
\hline & $\begin{array}{c}\text { Non- } \\
\text { Innovators }\end{array}$ & & ators & $\begin{array}{c}\text { Non- } \\
\text { Innovators }\end{array}$ & & tors \\
\hline Constant & $\begin{array}{c}-0.574 \\
(-1.356)\end{array}$ & $\begin{array}{c}0.148 \\
(0.958)\end{array}$ & $\begin{array}{c}0.059 \\
(0.482)\end{array}$ & $\begin{array}{c}-0.660 * * \\
(-2.153)\end{array}$ & $\begin{array}{c}-0.188 \\
(-1.331)\end{array}$ & $\begin{array}{c}-0.161 \\
(-1.163)\end{array}$ \\
\hline Part of Multi-plant Group & $\begin{array}{c}0.067 \\
(1.010)\end{array}$ & $\begin{array}{c}0.031 \\
(1.422)\end{array}$ & $\begin{array}{c}0.001 \\
(0.061)\end{array}$ & $\begin{array}{c}0.010 \\
(0.068)\end{array}$ & $\begin{array}{l}0.102 * \\
(1.746)\end{array}$ & $\begin{array}{c}0.087 \\
(1.520)\end{array}$ \\
\hline Graduate Employees & $\begin{array}{c}0.006 \\
(1.154)\end{array}$ & $\begin{array}{c}0.003 * * \\
(2.529)\end{array}$ & $\begin{array}{c}0.002 \\
(1.560)\end{array}$ & $\begin{array}{c}-0.003 \\
(-1.107)\end{array}$ & $\begin{array}{c}-0.000 \\
(-0.350)\end{array}$ & $\begin{array}{c}-0.002 * * \\
(-2.324)\end{array}$ \\
\hline R\&D Department in Plant & & $\begin{array}{c}-0.283 \\
(-1.186)\end{array}$ & $\begin{array}{c}-0.300 \\
(-1.436)\end{array}$ & $\begin{array}{c}0.587 \\
(1.391)\end{array}$ & $\begin{array}{c}0.736 * * \\
(3.170)\end{array}$ & $\begin{array}{c}0.929 * * \\
(3.982)\end{array}$ \\
\hline R\&D in Plant & $\begin{array}{c}0.158 * * \\
(2.124)\end{array}$ & $\begin{array}{c}-0.006 \\
(-0.259)\end{array}$ & $\begin{array}{c}0.009 \\
(0.434)\end{array}$ & $\begin{array}{c}0.257 \\
(1.620)\end{array}$ & $\begin{array}{c}0.131 * * \\
(3.771)\end{array}$ & $\begin{array}{c}0.105^{* *} \\
(3.118)\end{array}$ \\
\hline Plant Employment $\left(\mathrm{x} 10^{3}\right)$ & $\begin{array}{c}2.014 * * \\
(2.565)\end{array}$ & $\begin{array}{c}0.082 \\
(1.114)\end{array}$ & $\begin{array}{c}0.305 * * \\
(2.796)\end{array}$ & $\begin{array}{l}1.719 * * \\
(2.221)\end{array}$ & $\begin{array}{l}0.368 * * \\
(2.141)\end{array}$ & $\begin{array}{c}0.455^{* *} \\
(2.420)\end{array}$ \\
\hline Plant Employment (Squared) & $\begin{array}{l}-1.419 * \\
(-1.787)\end{array}$ & $\begin{array}{c}0.069 \\
(-0.809)\end{array}$ & $\begin{array}{l}-0.019 * \\
(-1.950)\end{array}$ & $\begin{array}{l}-0.644^{*} \\
(-1.800)\end{array}$ & $\begin{array}{c}-0.068 * * \\
(-1.977)\end{array}$ & $\begin{array}{c}-0.082 * * \\
(-2.165)\end{array}$ \\
\hline Regional GDP per Capita & $\begin{array}{c}0.038 \\
(1.312)\end{array}$ & $\begin{array}{c}0.001 * \\
(1.692)\end{array}$ & $\begin{array}{c}0.002 * * \\
(2.562)\end{array}$ & $\begin{array}{c}0.002 \\
(0.151)\end{array}$ & $\begin{array}{c}0.002 * * \\
(3.609)\end{array}$ & $\begin{array}{c}0.002 * * \\
(3.559)\end{array}$ \\
\hline Sector & $\begin{array}{c}0.081 \\
(1.630)\end{array}$ & $\begin{array}{c}0.126^{* *} \\
(3.603)\end{array}$ & $\begin{array}{c}0.111^{* *} \\
(3.619)\end{array}$ & $\begin{array}{c}-0.003 \\
(-0.030)\end{array}$ & $\begin{array}{c}-0.002 \\
(-0.014)\end{array}$ & $\begin{array}{c}0.001 \\
(0.065)\end{array}$ \\
\hline Region & $\begin{array}{c}-0.019 \\
(-0.190)\end{array}$ & $\begin{array}{c}-0.103 * * \\
(-2.555)\end{array}$ & $\begin{array}{c}-0.098 * * \\
(-2.700)\end{array}$ & $\begin{array}{c}-0.891 * * \\
(-3.316)\end{array}$ & $\begin{array}{c}-0.166 \\
(-1.610)\end{array}$ & $\begin{array}{c}-0.103 \\
(-1.053)\end{array}$ \\
\hline Supply Chain & $\begin{array}{c}0.046 \\
(0.054)\end{array}$ & $\begin{array}{c}-0.671 * * \\
(-2.120)\end{array}$ & $\begin{array}{c}-0.569 * * \\
(-2.196)\end{array}$ & $\begin{array}{c}2.299 * * \\
(4.658)\end{array}$ & $\begin{array}{c}0.072 \\
(0.286)\end{array}$ & $\begin{array}{c}0.142 \\
(0.557)\end{array}$ \\
\hline
\end{tabular}




\begin{tabular}{|c|c|c|c|c|c|c|}
\hline Sector x R\&D Department & & $\begin{array}{c}-0.056 \\
(-0.562)\end{array}$ & $\begin{array}{c}-0.042 \\
(-0.476)\end{array}$ & & $\begin{array}{c}0.042 \\
(0.339)\end{array}$ & $\begin{array}{c}0.048 \\
(0.397)\end{array}$ \\
\hline Region x R\&D Department & & $\begin{array}{c}0.168 \\
(1.523)\end{array}$ & $\begin{array}{l}0.178^{*} \\
(1.778)\end{array}$ & & $\begin{array}{c}-0.533^{* *} \\
(-3.167)\end{array}$ & $\begin{array}{c}-0.575^{* *} \\
(-3.409)\end{array}$ \\
\hline Supply Chain x R\&D Dept & & $\begin{array}{c}0.760 \\
(1.263)\end{array}$ & $\begin{array}{c}0.808 \\
(1.539)\end{array}$ & & $\begin{array}{c}-1.314^{* *} \\
(-2.244)\end{array}$ & $\begin{array}{r}-1.764^{* *} \\
(-3.018)\end{array}$ \\
\hline Innovation Intensity & & $\begin{array}{l}-0.011^{*} \\
(-1.652)\end{array}$ & & & $\begin{array}{c}-0.005 \\
(-0.372)\end{array}$ & \\
\hline Innovation Success $\left(\mathrm{x} 10^{2}\right)$ & & & $\begin{array}{c}-0.046 \\
(-1.156)\end{array}$ & & & $\begin{array}{l}-0.103^{*} \\
(-1.862)\end{array}$ \\
\hline $\mathrm{N}$ & 302 & 493 & 532 & 325 & 682 & 753 \\
\hline Log Likelihood & -178.18 & -137.47 & -142.55 & -174.41 & -193.52 & -228.61 \\
\hline
\end{tabular}

\section{Notes}

1. Reported coefficients are marginal values calculated at variable means. Observations were weighted to take account of sample structure and all equations included industry dummies that are not reported.

2. t-statistics in parentheses. Significant at $* * 5 \%, * 10 \%$ on a two-tailed test.

3. The percentages of correct predictions were as follows for the equations in columns (1) to (6): UK plants - 65.9 per cent, 90.7 per cent and 90.0 per cent; German plants - 72.9 per cent, 82.5 per cent and 81.8 per cent. 


\section{References}

Anderton, B., 1999. UK trade performance and the role of product quality, innovation and hysteresis: some preliminary results. Scottish Journal of Political Economy 46, 570-595.

Anderton, B., 1999a. Innovation, product quality, variety, and trade performance: an empirical analysis of Germany and the UK. Oxford Economic Papers 51, 152-167.

Audretsch, D., Menkveld, A. J., Thurik, A. R., 1996. The decision between internal and external R\&D. Journal of Institutional and Theoretical Economics 152, 517-530.

Audretsch, D., 1995. Innovation and Industry Evolution. MIT Press, Cambridge, Mass.

Baptista, R., Swann, P., 1998. Do firms in clusters innovate more? Research Policy 27, 525-540.

Becchetti, L., Rossi, S., 1998. The positive effects of industrial district on the export performance of Italian firms. Luiss Working Paper, No. 54.

Bernard, A. B., Jensen J. B., 1999. Exceptional export performance: cause, effect, or both?. Journal of International Economics 47, 1-25.

Bernard, A. B., Wagner, J., 1997. Exports and success in German manufacturing. Weltwirtschaftliches Archiv 133, 134-157.

Braunerhjelm, P., 1996. The relation between firm-specific intangibles and exports. Economics Letters 53, 213-219.

Brouwer, E., Kleinknecht, A., 1996. Determinants of innovation: a microeconometric analysis of three alternative innovation output indicators. In: Kleinknecht, A. (Ed.). Determinants of Innovation: the Message from New Indicators. Macmillan, London and Basingstoke:.

Buxton, T., Mayes, D., Murfin, A., 1991. UK Trade Performance and R\&D. Economics of Innovation and New Technology 1, 243-256.

Cefis, E., Orsenigo, L., 2001. The persistence of innovative activities: a crosscountries and cross-sector comparative analysis. Research Policy 30, 1139-1158.

Cohen, W., 1995. Empirical studies of innovative activity. In: Stoneman, P. (Ed.). Handbook of the Economics of Innovation and Technological Change. Basil Blackwell, Oxford.

Cooke, P., et al. 1998. REGIS Project - Regional Innovation Systems: Designing for the Future. European Commission, Final Report of Project ERB-SOE1-CT-95-1010.

Cragg, J., 1971. Some statistical models for limited dependent variables with application to the demand for durable goods. Econometrica 39, 829-844. 
Crone, M., Roper, S., 2001. Local learning and the supply chain: knowledge transfers from multi-national plants. Regional Studies, forthcoming.

Dobkins, L. H., 1996. Location, innovation and trade: the role of localisation and nation-based externalities. Regional Science and Urban Economics 26, 591-612.

Gemser, G., Wijnberg, N. M., 1995. Horizontal networks, appropriability conditions and industry life cycles. Journal of Industry Studies 2, 129-140.

Geroski, P., 1991. Innovation and the sectoral sources of UK productivity growth. Economic Journal 101, 1438-1451.

Geroski, P., Machin, R., Van Reenen, J., 1993. The profitability of innovating firms. RAND Journal of Economics 24, 198-211.

Geroski, P., Van Reenen, J., Walters, C. F., 1997. 'How persistently do firms innovate?. Research Policy 26, 33-48.

Görg, H., Ruane, F., 2000. An analysis of backward linkages in the Irish electronics sector. The Economic and Social Review. 31, 3, 215-235.

Grabher, G., Stark, D., 1997. Organising diversity: evolutionary theory, network analysis and post-socialism. Regional Studies 31, 533-544.

Greene, W. H., 1993. Econometric Analysis. Macmillan, New York.

Greenhalgh, C., 1990. Innovation and trade performance in the UK. Economic Journal 100, 105-118.

Greenhalgh, C., Taylor, P., and Wilson, R., 1994. Innovation and export volumes and prices: a disaggregated study. Oxford Economic Papers 46, 102-134.

Hertog, R. G. J. den, Thurik, A. R., 1993. Determinants of internal and external R\&D: Some Dutch evidence. De Economist 141, 279-89.

Hirsch, S., and Bijaoui, I., 1985. R\&D intensity and export performance: a micro view. Weltwirtshaftliches Archiv 121, 138-251.

Ioannidis, E., Schreyer, P., 1997. Technology and non-technology determinants of export share growth. OECD Economic Studies, 28, 1997/1

Ito, K., Pucik, V., 1993. R\&D spending, domestic competition, and export performance of Japanese manufacturing firms. Strategic Management Journal 14, 61-75.

Karunaratne, N. D., 1997. High-tech innovation, growth and trade dynamics in Australia. Open Economies Review 8, 151-170. 
Kleinknecht, A., 1996. Determinants of Innovation: The Message from New Indicators. Macmillan, London and Basingstoke.

Kumar, N., Siddharthan, N. S., 1994. Technology, firm size and export behaviour in developing countries. Journal of Development Studies 32, 288-309.

Lefebvre, E., Lefebvre, L.A., Bourgault, M., 1998. R\&D-related capabilities as determinants of export performance. Small Business Economics 10, 365-377.

Love, J. H., Roper, S., 2001. Location and network effects on innovation success: evidence for UK, Irish and German manufacturing plants. Research Policy 30, 643661.

Love, J. H., Roper, S., 2002. Internal versus external R\&D: an study of R\&D choice with sample selection. International Journal of the Economics of Business, forthcoming.

Magnier, A., Toujas-Bernate, J., 1994. Technology and trade: empirical evidence for the five major European countries. Weltwirtschaftliches Archiv 130, 494-520.

Maillat, D., 1991. Local dynamism, milieu and innovative enterprises. In: Brotchie, J., Batty, M., Hall, P., Newton, P., (Eds.) Cities of the $21^{\text {st }}$ Century. Longman, Harlow.

Mason, C., Wagner, K., 1994. Innovation and the skill mix: chemicals and engineering in Britain and Germany. National Institute Economic Review, May, 6172 .

Metcalfe, S., 1997. Technology systems and technology policy in an evolutionary framework. In: Archibugi, D., Michie, J., (Eds), Technology, Globalisation and Economic Performance. Cambridge University Press.

Morgan, K., 1997. The learning region: institutions, innovation and regional renewal. Regional Studies. 31, 491-503.

Oerlemans, L. A. G., Meus, M. T. H., Boekema, F. W. M., 1998. Do networks matter for innovation? The usefulness of the economic network approach in analysing innovation. Tijdschrift voor Economische en Sociale Geografie 89, 298-309.

Posner, M., 1961. International trade and technical change. Oxford Economic Papers $13,323-41$.

Powell, W. W., 1998. Learning from collaboration: knowledge and networks in the biotechnology and pharmaceutical industries. California Management Review 40, 228-240.

Roper, S., 1997. Product innovation and small business growth; a comparison of the strategies of German, UK and Irish companies. Small Business Economics 9, 523537. 
Roper, S., 2000. Benchmarking regional innovation: a comparison of BadenWürttemberg, Bavaria, Northern Ireland and the Republic of Ireland. Working Paper 57, NIERC, Queen's University Belfast.

Roper, S., Ashcroft, B., Love, J. H., Dunlop, S., Vogler-Ludwig, K., Hofmann, H., 1996. Product Innovation and Development in UK, German and Irish Manufacturing Firms. NIERC/Fraser of Allander Institute.

Shefer, D., Frenkel, A., 1998. Local milieu and innovations: some empirical results. Annals of Regional Science 32, 185-200.

Sterlacchini, A., 1999. Do innovative activities matter to small firms in non-R\&Dintensive industries? An application to export performance. Research Policy 28, 819832.

Thirwall, A., 1986. Balance of Payments Theory and the UK Experience. Macmillan, London.

Vernon, V., 1966. International investment and international trade in the product cycle. Quarterly Journal of Economics 80, 190-207.

Veugelers, R., Cassiman, B., 1999. Make and buy in innovation strategies: evidence from Belgian manufacturing firms. Research Policy 28, 63-80.

Wagner, J., 1995. Exports, firm size, and firm dynamics. Small Business Economics 7, 29-39.

Wakelin, K., 1998. The role of innovation in bilateral OECD trade performance. Applied Economics 30, 1335-1346.

Wakelin, K., 1998a. Innovation and export behaviour at the firm level. Research Policy 26, 829-841.

Willmore, L., 1992. Transnationals and foreign trade: evidence from Brazil. Journal of Development Studies 28, 314-335. 